\title{
Physicochemical Parameters and Planktonic Species as Indicators to Assess Water Quality of River Basin and Winam (Nyanza) Gulf of Lake Victoria Catchment, Kisumu County, Kenya (East Africa)
}

\section{Manohar S}

Department of Environmental Sciences, Kenyatta University P.O Box 43844-00100, Nairobi, Kenya

"Corresponding author: Manohar S, Department of Environmental Sciences, Kenyatta University P.O Box 43844-00100, Nairobi, Kenya, Tel: +254738974888; E-mail: prof.dr.smanohar@gmail.com

Received: April 09, 2018; Accepted: April 21, 2018; Published: April 28, 2018

Copyright: (C) 2018 Manohar S. This is an open-access article distributed under the terms of the Creative Commons Attribution License, which permits unrestricted use, distribution, and reproduction in any medium, provided the original author and source are credited.

\begin{abstract}
Presence (+) or absence (-) of planktonic species is the direct indication of differences in physicochemical characteristics of water because all living microorganisms appear, survive, develop and multiply in suitable specific habitats within an aquatic ecosystem. Planktonic species as indicators with relation to physicochemical parameters were studied to assess water quality of ten selected (S1-S10) sampling stations along Nyalenda swamp (S1), River Kisat (S2-S5) and part of Winam (Nyanza) Gulf (S6-S10) within Lake Victoria Catchment in Kisumu County, Kenya (East Africa). There are 14 genera (Amphora, Aulacoseira, Closterium, Cyclotella, Cymbella, Diatoma, Fragillaria, Gomphocymbella, Navicula, Nitzschia, Pinnularia, Stephomodiscus, Surillela and Synedra) composed of 28 planktonic species. During the field study, Genera Nitzschia is represented by its five species but only four species $N$. lucastris; $N$. palea; $N$. recta and $N$. sub-acicularis together with other three genera and four species which are Cymbella cistula; Cymbella sp; Diatoma hiemiale; Navicula granatum are present with $100 \%$ frequency in all the ten sampling stations (S1-S10) and very well adapted within wide range of $\mathrm{pH}$, dissolved oxygen, conductivity, turbidity, alkalinity, total nitrogen and phosphorus levels. Six species belong to five genera: Aulacoseira ambigua; Aulacoseira nyassensis; Cyclotella kutzinghiana; Diatoma elongatum; Navicula sp; and Surilella ovalis appeared with $80 \%$ frequency. There are six genera: Amphora, Cyclotella, Cymbella, Fragillaria, Navicula and Synedra represented by two species each, while other five genera including Closterium, Gomphocymbella, Pinnularia, Stephomodiscus and Surillela are represented with one single species each. There are two species of genera Amphora but only one Amphora sp appeared with $70 \%$ frequency. Three planktonic species: Nitzschia dessipata, Synedra cunningtonii and Synedra ulna are with $60 \%$ frequency; three species: Amphora ovalis; Fragilaria aethiopica; and Stephomodiscus astraca appear with $50 \%$ frequency; two species: Aulacoseira schroidera and Cyclotella ocellata are with $30 \%$ frequency; and three species: Closterium aciculare, Diatoma valgare and Pinnularia viridis appeared with $20 \%$ frequency and lastly, other two remaining species: Fragillaria longissimi and Gomphocymbella beccari are present only in sampling station (S5) with $10 \%$ frequency. Each planktonic species is an indicator species of its own low or high levels of physicochemical parameters. Study revealed that mean monthly values of physicochemical levels of $\mathrm{pH}$, dissolved oxygen, alkalinity and silicate show significant difference $(\mathrm{p}=0.001 \leq 0.05)$ but electrical conductivity $(381.25 \mu \mathrm{S} / \mathrm{cm}$ to $839.65 \mu \mathrm{S} / \mathrm{cm}$ ), turbidity (32.37 NTU to $134.98 \mathrm{NTU}$ ), total nitrogen (388.56 $\mu \mathrm{g} / \mathrm{l}$ to $908.88 \mu \mathrm{g} / \mathrm{l})$, phosphorus $(329.21 \mu \mathrm{g} / \mathrm{l}$ to $1246.38 \mu \mathrm{g} / \mathrm{l})$ levels are higher than permissible standards of WHO, EU, KEBS and NEMA. Based on these results, these water bodies are polluted and not good source for drinking water. It is recommended that planktonic species should be used in the field as quick bio-indicator(s) to assess the water quality of any global aquatic ecosystem(s).
\end{abstract}

Keywords: Physicochemical parameters; Planktonic species; Indicators; Water quality

\section{Introduction}

Mostly in East African countries, especially in Kenya, topography of the land is uneven and human population mainly depends on surface water for their requirements. Presence of planktonic species, their growth, composition, distribution, densities and association depend on qualitative and quantitative physicochemical parameters of the water body, its volume, depth and flow rate within habitats; interactions between biotic and abiotic components of the surrounding environment; seasonal variations; types, frequency and quantities of nutrients and sediments load; producers and consumers ratio within the water of swamps/rivers/dams or lakes. Impacts of anthropogenic activities due to human population explosion, rate of deforestation, heavy industrialization, excessive use of agrochemicals, sediment load, water runoff; flooding, decomposition of organic matter and discharge of untreated industrial, municipal and household wastes are the main causes of high pollution levels in water bodies within underdeveloping countries of African and Asian continents. Normally, water body supports all types of diverse microorganisms belong to Prokaryotes and various forms of Eukaryotes but polluted water only support specific species of microorganisms depending upon the quality and quantity of contaminants.

All categories of hydrophytes play a significant role in an aquatic ecosystem and their stratification (i) free floating, (ii) attached floating (iii) submerged and (iv) emergent species depends on the interaction of biological, physical, chemical characteristics of water and other environmental variables such as light intensity, duration and quality, temperature fluctuations, intensity of turbulent mixing, benthic feeds and seasonal fluctuations [1]. Diversity of algal species and their high 
Citation: Manohar S (2018) Physicochemical Parameters and Planktonic Species as Indicators to Assess Water Quality of River Basin and Winam (Nyanza) Gulf of Lake Victoria Catchment, Kisumu County, Kenya (East Africa). J Environ Anal Toxicol 8: 560. doi: $10.4172 / 2161-0525.1000560$

Page 2 of 9

densities indicate warning signs of deteriorating water conditions [2] Diatoms are useful in indicating specific water quality problems such as organic pollution, eutrophication and heavy metal pollution [3]. Species composition or the communities of micro and macrohydrophytes are the best indicators to monitor and assess the water quality of any natural or manmade wetlands [4]. Phytoplankton which inhibit the upper eutrophic layer are the main causes of high turbidity if density increases [5]. Nutrient enrichment has the direct impacts on the composition of planktons, algal flora, aquatic angiosperms and other organisms which influence and alter the structure and function of any aquatic ecosystem $[4,6]$.

Eutrophication of water is often linked with increased productivity, over simplification of the biotic communities, and a consequent decrease in metabolism of bottom-dwelling species that are unable to cope with the associated increase in nutrient loading [7]. In all global aquatic ecosystems, species composition of micro and macro organisms, abundance, growth, development and their distribution depend on quantity of contaminants, types of contamination, levels of chemical concentrations, sediments load; electrical conductivity, turbidity, seasonal variations; depth, width, flow rate, number of inlets and outlets with volume of water and also the impacts of anthropogenic activities always reflect on the water quality of a wetland [8]. Eutrophication leads to change the community structure, devastating impacts on food web, and alterations in biogeochemical cycles $[9,10]$. Eutrophic lowland reservoir leads in shaping the composition of river phytoplankton [11].

Variations in environmental factors have direct influence on the Phytoplankton composition [12]. Seasonal variations and physicochemical concentrations has been used to monitor the water quality of urban River Ala in South-western-Nigeria [13]. Physicochemical characteristics in the Filling Phase of Bakun Hydroelectric Reservoir, Sarawak, Malaysia, were used to assess the water quality [14]. Physicochemical factors were used to monitor water quality of Malaprabha River [15]. There is a direct link between physicochemical and microbial status [16]. Physicochemical parameters are the indicators to determine the water quality with its index [17].

There is strong correlation between $\mathrm{pH}$, dissolved oxygen, alkalinity, conductivity, substratum conditions, structure of the diatom community and concluded that diatoms and soft algae are the indicators of environmental determinants in the Lahontan Basin, USA [18], changes in diatom community structures are the indicators of water quality in urban and agriculturally stressed rivers [19]. Diatoms and Macroinvertebrate assemblages are biological indicators of water quality [20]. Diatoms, macroinvertebrates and chemical parameters are good indicators for comparative monitoring of water quality [21]. Diatoms are the indicators for comparable habitats of the European Inland Waters [22]. Periphyton index of biotic Integrity are good indicators for the assessment of streams of the eastern United States [23].

Diatoms are bio-monitoring tool and indicative of the effects of specific water quality problems and changes in water chemistry [24]. Diffuse pollution from acid mine drainage inhibit the multiplication of some species of diatoms are the added value bio-monitoring tool [25]. High concentrations of heavy metals show negative impacts on the diatom community, causing frustule deformities and loss of their diversity [24,26]. Diatom community structures in urban and agriculturally stressed rivers [19], macroinvertebrate assemblages [20] and phytoplankton community structure [27] were studied as biological indicators of water quality and concluded that domestic wastes, industrial inputs, agricultural runoff and sewage disposal are the main causes of high nutrient levels in surface waters daily activities of local people and their livestock reflects on poor water quality $[19,20,27]$.

Algal communities, their taxonomic composition and growth are strongly influenced by water chemistry and respond predictably and sensitively to nutrient enrichment, organic contamination, pesticides, changes in $\mathrm{pH}$ and conductivity [28]. There is strong link between nutrient availability and diatom community structure [23]. Phytoplankton species depend mainly on the availability of nutrients, light and temperature [12]. Variations in diatom community depend directly on the nutrient presence [21]. Water pollution associated with agricultural systems, industrial, household and municipal wastes, animal dung/manure, nitrates, phosphates and other chemical fertilizers, heavy metals, pathogens and sediment load cause serious ecological ramifications that pass through food chains to humans [24]. Water quality of the lake depends on the growth of planktonic diatoms and level of pollution within fresh water rivers [29]. Effect of urbanization has the direct impact on surface water chemistry in south-central Texas, USA [30], hematological and biochemical parameters were studied in common carp (Cyprinus carpio L.1758) in Munzur River of Turkey [31] and concluded that some hazardous substances or products that contain harmful elements which are not degradable in the environment and may cause deleterious effects to the health $[30,31]$.

\section{Materials and Methods}

\section{Study area}

Study was carried out at Nyalenda Swamp, the origin of river Kisat and merges in Winam (Nyanza) Gulf of Lake Victoria catchment within Kisumu County which is about $500 \mathrm{~km}$ on western side from Nairobi, the capital city of Kenya (Figure 1). It is situated at the latitude of $0018^{\prime}$ S to 00 04' north and longitude of $34043^{\prime} 350$ 30'east and at an altitude of $1133 \mathrm{~m}$ above the sea level. Annual average rainfall is about $1250 \mathrm{~mm}$, temperature $25^{\circ} \mathrm{C}$ and wind velocity is $15 \mathrm{Km} / \mathrm{h}$. Geology of the area is volcanic in origin and soil types are the mixture of clay, loam and sand. Some common species of angiosperms around the periphery of the wetland are Ipomea aquatica, Vigna luteola and Sesbania goetzei; attached emergent amphibious hydrophytes (Polygonum salicifolium; Typha domingensis, Cyprus papyrus); but free-floating species are Pistia stratiotes, Salvinia auriculata and Eichhornia crassipes.

The human population is approximately 410,200 people in Kisumu area and main socio-economic activities are fishing, farming, labors and small business. Mostly low-income group people stay in Obunga slum under poor infrastructure, no sanitation, no awareness of any type of waste management, no assistance from the local government, and no enforcement of environmental laws by Kisumu County officials. Therefore, dumping/discharging/disposal of all types of wastes are common practice by local communities along the swamp and allover surrounding areas of river basin and Winam (Nyanza) Gulf. 
Citation: Manohar S (2018) Physicochemical Parameters and Planktonic Species as Indicators to Assess Water Quality of River Basin and Winam (Nyanza) Gulf of Lake Victoria Catchment, Kisumu County, Kenya (East Africa). J Environ Anal Toxicol 8: 560. doi: $10.4172 / 2161-0525.1000560$

Page 3 of 9

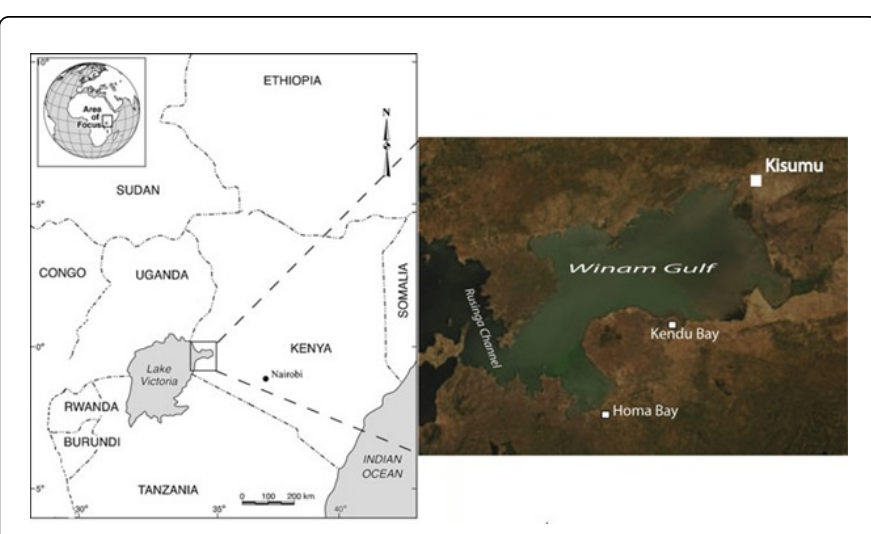

Figure 1: Map of East African countries sharing Lake Victoria with emphasis on the portion of Winam (Nyanza) Gulf with its enlarged satellite image within Kenyan territory.

\section{Data collection and analysis}

In total 10 sampling stations were selected but each station is at the distance of about $2 \mathrm{~km}$ from each other along Nyalenda swamp, river Kisat basin and Winam/Nyanza Gulf. Sampling station S1 is located within swamp; station S2 and S3 are located before and after slum respectively; station S4 is located after sewerage treatment plant; sampling station S5 is after discharge of industrial and municipal wastes; sampling station $\mathrm{S} 6$ is at the downstream junction where River Kisat joins Winam (Nyanza) Gulf which have four (S7 to S10) sampling stations (Figure 2).

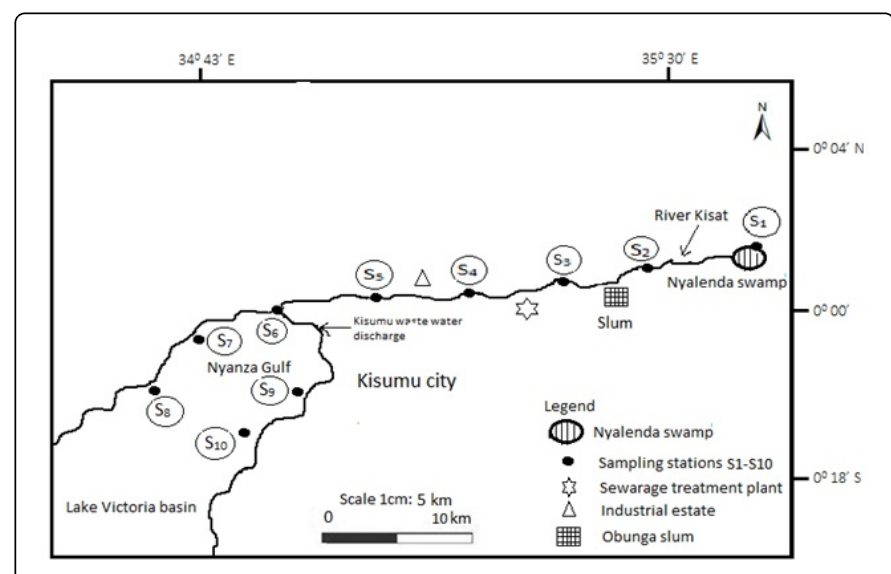

Figure 2: Map of study area shows ten selected data sampling stations (S1-S10) along Nyalenda Swamp(S1), River Kisat (S2-S5) and Winam (Nyanza) Gulf (S6-S10) part of Lake Victoria, Kisumu County, Kenya (February-July 2017).

To study planktonic species, water samples were collected once in a month between 7.00 am and 10.00 am for six months (February-July 2017) from all the ten (S1-S10) sampling stations (Figure 2) by scooping water at the depth of $15-30 \mathrm{~cm}$ below the water surface and filtered through a plankton net with pore size of $64 \mu \mathrm{m}$, transferred into $100 \mathrm{ml}$ glass bottles and fixed with acidic Lugol's Iodine solution before transporting to laboratory for identification of species and water analysis. To study planktonic species /diatoms, one drop or $0.2 \mathrm{ml}$ of water from each sample was placed in an Utermohl sampling chamber and kept at least for three hours to get settled [2]. Species were studied using a Zeiss Axioinvert 35 inverted microscope at 40X magnification, identified and confirmed with taxonomic keys [22,32-38].

Selected physical parameters were recorded in the field by using instruments which were calibrated before each data collection during sampling trip [2]. Water temperature and electrical conductivity were measured by using portable multi-electrode water testing kit (Portable OakTon 510 series), dissolved oxygen, $\mathrm{pH}$ and turbidity were measured using a portable CX-401 multifunctional data logger and Turbidity meter. Current meter was used to record flow rate of water during field study period. For chemical analysis, all plastic sampling bottles of 500 $\mathrm{ml}$ were soaked in $10 \% \mathrm{HCl}$, cleaned and rinsed with distilled water. Samples were collected once in a month from February-July 2017 between 07 am and 10 am from all the ten sampling sites (S1-S10) by scooping water below the surface at the of depth of $15-30 \mathrm{~cm}$ and fixed with $0.2 \mathrm{M} \mathrm{H}_{2} \mathrm{SO}_{4}$, firmly corked, kept in an ice box at $4^{\circ} \mathrm{C}$ and transported to the laboratory of Kenya Marine and Fisheries Research Institute, Kisumu. All these 60 water samples were collected and analyzed following the standard methods [2]. Total alkalinity was determined by titration method; total phosphorus, total nitrogen and silicates were analyzed by Calorimetric method using UV/VIS spectroscopy machine $\mathrm{T} 80^{+}[2]$. Chlorophyll-a was extracted by using $90 \%$ acetone [7].

\section{Results and Discussion}

\section{Physico-chemical parameters}

Water quality was determined by measuring the temperature ${ }^{\circ} \mathrm{C}$, flow rate, $\mathrm{pH}$, dissolved oxygen, conductivity, turbidity and also by analyzing alkalinity, total nitrogen, total phosphate, silicate and chlorophyll-a on monthly basis for six months from February to July 2017.

Mean monthly minimum $\left(24.82 \pm 0.78^{\circ} \mathrm{C}\right)$ and maximum $(27.87 \pm$ $0.54^{\circ} \mathrm{C}$ ) temperature of the water was recorded at sampling station S2 and $\mathrm{S} 5$ respectively but the average temperature is $26.21 \pm 0.55^{\circ} \mathrm{C}$ of all the ten (S1-S10) sampling stations (Table 1). ANOVA test revealed that the recorded $\mathrm{p}$-value of temperature at all the ten sampling sites is not significantly different $(p=0.427>0.05)$. Water temperature of the wetlands always depends on altitude, topography, changes in weather patterns, seasonal fluctuations; duration, quality and intensity of solar radiation; cloud cover, humidity; width, depth, flow rate of water; sediments load, presence or absence of type of organisms and their stratification; suspended solids within the water body of an area/ region.

Flow rate of water varies between $1.2 \pm 0.03 \mathrm{~km} / \mathrm{h}$ and $1.7 \pm 0.06$ $\mathrm{km} / \mathrm{h}$ within all ten sampling stations (Table 1 ). The lowest flow rate $(1.2 \pm 0.03 \mathrm{~km} / \mathrm{h})$ was recorded at sampling station (S1) due to even topography and excessive growth of attached emergent amphibious angiosperms Typha domingensis mixed with Cyprus papyrus along the periphery; free floating Pistia sp, submerged angiosperms, algae, zooplanktons and planktonic diatoms suspended within all (S1-S10) sampling stations (Figure 2). High flow rate is $(1.7 \pm 0.06 \mathrm{~km} / \mathrm{h})$ at station S5 mainly due to heavy discharge of effluents from Obunga slum, sewage treatment plant and also from industries. ANOVA test shows no significant difference $(\mathrm{p}=0.376>0.05)$ in flow rate within all sampling stations. Normally, flow rate depends on gravity; frequency, intensity, quantity of rain and its volume; number of inlets and outlets, 
Citation: Manohar S (2018) Physicochemical Parameters and Planktonic Species as Indicators to Assess Water Quality of River Basin and Winam (Nyanza) Gulf of Lake Victoria Catchment, Kisumu County, Kenya (East Africa). J Environ Anal Toxicol 8: 560. doi: $10.4172 / 2161-0525.1000560$

Page 4 of 9

depth and width; growth, distribution and stratification of hydrophytes within the water body [8]. Nyalenda swamp (S1) is the main source of water for River Kisat and is a small water body flows on even topography, covers short distance of about $12 \mathrm{~km}$ with its width between $0.7 \mathrm{~m}$ at upstream and $4.6 \mathrm{~m}$ at the river mouth (S6) with maximum depth of $0.5 \mathrm{~m}$ with low water volume drains in Winam Gulf (Figure 2).

\begin{tabular}{|c|c|c|c|c|c|c|c|c|c|c|c|}
\hline \multirow{2}{*}{$\begin{array}{l}\text { Sampling } \\
\text { Stations }\end{array}$} & \multicolumn{6}{|c|}{ Physical Parameters } & \multicolumn{5}{|c|}{ Chemical Parameters } \\
\hline & $\begin{array}{l}\text { Temperature } \\
\left({ }^{\circ} \mathrm{C}\right)\end{array}$ & $\begin{array}{l}\text { Flow } \\
\text { rate } \\
(\mathrm{Km} / \mathrm{h})\end{array}$ & pH & $\begin{array}{l}\text { Dissolved } \\
\text { oxygen } \\
(\mathrm{mg} / \mathrm{l})\end{array}$ & $\begin{array}{l}\text { Electrical } \\
\text { Conductivity } \\
(\mu \mathrm{S} / \mathrm{cm})\end{array}$ & $\begin{array}{l}\text { Turbidity } \\
\text { (NTU) }\end{array}$ & $\begin{array}{l}\text { Alkalinity } \\
\text { (mg/l) }\end{array}$ & \begin{tabular}{|l} 
Total \\
nitrogen \\
$(\mu \mathrm{g} / \mathrm{l})$
\end{tabular} & $\begin{array}{l}\text { Total } \\
\text { phosphorus } \\
(\mu \mathrm{g} / \mathrm{l})\end{array}$ & \begin{tabular}{|l} 
Silicate \\
(mg/l)
\end{tabular} & $\begin{array}{l}\text { Chlorophyll- } \\
\text { a (mg/l) }\end{array}$ \\
\hline s1 & $25.29 \pm 0.65$ & $\begin{array}{ll}1.2 & \pm \\
0.03 & \end{array}$ & $\begin{array}{ll}6.96 & \pm \\
0.38\end{array}$ & $5.98 \pm 0.54$ & $\begin{array}{l}381.25 \\
20.45\end{array}$ & $\begin{array}{ll}32.37 & \pm \\
5.21 & \end{array}$ & $\begin{array}{l}96.28 \\
45.24\end{array}$ & $\begin{array}{l}388.56 \\
68.25\end{array}$ & $\begin{array}{l}329.21 \\
102.54\end{array}$ & $\begin{array}{l}4.10 \\
0.76\end{array}$ & $93.57 \pm 20.26$ \\
\hline S2 & $24.82 \pm 0.78$ & $\begin{array}{ll}1.4 & \pm \\
0.05 & \end{array}$ & $\begin{array}{l}7.24 \\
0.16\end{array}$ & $5.32 \pm 0.75$ & $\begin{array}{l}390.75 \\
28.40\end{array}$ & $\begin{array}{l}62.35 \\
10.22\end{array}$ & $\begin{array}{l}98.58 \\
22.27\end{array}$ & $\begin{array}{l}400.77 \quad \pm \\
124.50\end{array}$ & $\begin{array}{l}342.17 \\
112.48\end{array}$ & $\begin{array}{l}4.12 \\
0.65\end{array}$ & $97.82 \pm 21.15$ \\
\hline S3 & $25.78 \pm 0.67$ & $\begin{array}{l}1.5 \quad \pm \\
0.06\end{array}$ & \begin{tabular}{|l|}
8.21 \\
0.17
\end{tabular} & $4.11 \pm 0.71$ & $\begin{array}{l}802.64 \\
33.17\end{array}$ & $\begin{array}{l}98.14 \\
8.85\end{array}$ & $\begin{array}{l}114.36 \quad \pm \\
25.54\end{array}$ & $\begin{array}{l}629.71 \\
185.14\end{array}$ & \begin{tabular}{|l|}
776.14 \\
122.81
\end{tabular} & $\begin{array}{l}4.14 \\
0.75\end{array}$ & $\begin{array}{l}105.86 \\
24.59\end{array}$ \\
\hline S4 & $25.85 \pm 0.71$ & $\begin{array}{ll}1.3 & \pm \\
0.03 & \end{array}$ & $\begin{array}{l}8.52 \\
0.48\end{array}$ & $3.32 \pm 0.69$ & $\begin{array}{l}796.45 \\
23.32\end{array}$ & $\begin{array}{ll}107.73 & \pm \\
17.15\end{array}$ & $\begin{array}{l}164.51 \quad \pm \\
28.93\end{array}$ & $\begin{array}{ll}720.87 & \pm \\
287.87 & \end{array}$ & $\begin{array}{l}1028.77 \\
361.48\end{array}$ & $\begin{array}{l}4.46 \\
1.02\end{array}$ & $\begin{array}{l}153.98 \\
33.46\end{array}$ \\
\hline s5 & $27.87 \pm 0.54$ & $\begin{array}{ll}1.7 & \pm \\
0.06 & \end{array}$ & $\begin{array}{l}9.98 \\
0.36\end{array}$ & $3.19 \pm 0.42$ & $\begin{array}{l}839.65 \\
39.15\end{array}$ & $\begin{array}{ll}134.98 & \pm \\
18.97\end{array}$ & $\begin{array}{l}199.32 \quad \pm \\
29.58\end{array}$ & $\begin{array}{ll}908.88 & \pm \\
363.96\end{array}$ & $\begin{array}{l}1246.38 \\
424.28\end{array}$ & $\begin{array}{l}4.58 \\
1.65\end{array}$ & $\begin{array}{l}186.88 \\
35.15\end{array}$ \\
\hline S6 & $27.63 \pm 0.42$ & $\begin{array}{ll}1.3 & \pm \\
0.04 & \end{array}$ & $\begin{array}{l}8.83 \\
0.25\end{array}$ & $3.12 \pm 0.40$ & $\begin{array}{l}799.43 \\
33.11\end{array}$ & $\begin{array}{l}108.35 \\
21.55\end{array}$ & $\begin{array}{l}171.16 \quad \pm \\
28.18\end{array}$ & $\begin{array}{ll}877.14 & \pm \\
208.78 & \end{array}$ & $\begin{array}{l}1164.24 \\
346.31\end{array}$ & \begin{tabular}{|l|}
3.8 \\
0.37
\end{tabular} & \begin{tabular}{|l|}
223.14 \\
74.30
\end{tabular} \\
\hline S7 & $27.58 \pm 0.52$ & $\begin{array}{ll}1.4 & \pm \\
0.05 & \end{array}$ & $\begin{array}{l}8.65 \\
0.38\end{array}$ & $3.34 \pm 0.56$ & $\begin{array}{l}569.15 \\
25.46\end{array}$ & $\begin{array}{l}78.14 \\
12.18\end{array}$ & $\begin{array}{l}114.38 \quad \pm \\
19.27\end{array}$ & $\begin{array}{ll}804.89 \\
133.25\end{array}$ & \begin{tabular}{|l|}
885.24 \\
133.25
\end{tabular} & $\begin{array}{l}4.05 \\
0.54\end{array}$ & $\begin{array}{l}182.89 \\
88.38\end{array}$ \\
\hline S8 & $25.69 \pm 0.43$ & $\begin{array}{ll}1.5 & \pm \\
0.06 & \end{array}$ & $\begin{array}{l}8.21 \\
0.16\end{array}$ & $4.35 \pm 0.37$ & $\begin{array}{l}541.57 \\
20.52\end{array}$ & $\begin{array}{l}72.43 \\
16.28\end{array}$ & $\begin{array}{l}99.23 \\
20.37\end{array}$ & $\begin{array}{l}600.35 \\
129.14\end{array}$ & \begin{tabular}{|l|}
641.35 \\
113.36
\end{tabular} & $\begin{array}{l}4.42 \\
1.56\end{array}$ & $\begin{array}{l}122.46 \\
86.27\end{array}$ \\
\hline s9 & $25.95 \pm 0.35$ & $\begin{array}{ll}1.4 & \pm \\
0.04 & \end{array}$ & $\begin{array}{ll}8.85 & \pm \\
0.24 & \end{array}$ & $3.31 \pm 0.19$ & $\begin{array}{l}665.91 \\
35.53\end{array}$ & $\begin{array}{l}85.37 \\
17.59\end{array}$ & $\begin{array}{l}112.33 \quad \pm \\
26.52\end{array}$ & $\begin{array}{ll}768.46 & \pm \\
138.38\end{array}$ & \begin{tabular}{|l|}
895.45 \\
136.06
\end{tabular} & $\begin{array}{l}4.51 \\
1.60\end{array}$ & $\begin{array}{l}165.48 \\
90.56\end{array}$ \\
\hline S10 & $25.61 \pm 0.34$ & $\begin{array}{ll}1.4 & \pm \\
0.04 & \end{array}$ & $\begin{array}{ll}8.34 & \pm \\
0.48\end{array}$ & $4.23 \pm 0.27$ & $\begin{array}{l}657.31 \\
25.65\end{array}$ & $\begin{array}{l}80.42 \\
24.13\end{array}$ & $\begin{array}{l}104.45 \quad \pm \\
68.19\end{array}$ & $\begin{array}{l}611.38 \\
130.58\end{array}$ & $\begin{array}{l}657.56 \\
118.56\end{array}$ & $\begin{array}{l}4.49 \\
1.59\end{array}$ & $\begin{array}{l}138.45 \\
90.23\end{array}$ \\
\hline $\begin{array}{l}\text { Average } \\
\text { values }\end{array}$ & $26.21 \pm 0.55$ & $\begin{array}{ll}1.41 & \pm \\
0.05 & \end{array}$ & $\begin{array}{l}8.38 \\
0.31\end{array}$ & $4.03 \pm 0.49$ & $\begin{array}{l}644.42 \\
28.48\end{array}$ & $\begin{array}{l}86.03 \\
15.22\end{array}$ & $\begin{array}{l}127.46 \quad \pm \\
31.41\end{array}$ & $\begin{array}{l}671.11 \quad \pm \\
176.99\end{array}$ & $\begin{array}{l}796.66 \\
197.12\end{array}$ & $\begin{array}{l}4.27 \\
1.05\end{array}$ & $\begin{array}{l}147.06 \\
56.44\end{array}$ \\
\hline $\begin{array}{l}p \text {-values (p } \\
\leq 0.05)\end{array}$ & $p=0.427$ & $p=0.376$ & $p=0.001$ & $p=0.001$ & $\mathrm{p}=0.327$ & $p=0.128$ & $p=0.001$ & $p=0.421$ & $p=0.419$ & $p=0.004$ & $p=0.446$ \\
\hline
\end{tabular}

Table 1: Mean monthly values of physical \& chemical parameters of all water samples collected from selected ten (S1-S10) sampling stations: i.e., Nyalenda swamp (S1) River Kisat (S2 to S5), and Winam Gulf (S6 to S10) part of Lake Victoria Catchment in Kisumu County, Kenya, East Africa (February to July 2017).

Mean monthly $\mathrm{pH}$ varies between $(6.96 \pm 0.38)$ and $(9.98 \pm 0.36)$ at station $\mathrm{S} 1$ and $\mathrm{S} 5$ respectively and overall average value of $\mathrm{pH}$ is $8.38 \pm$ 0.31 (Table 1). Using ANOVA test, $\mathrm{p}$-value $(\mathrm{p}=0.001 \leq 0.05)$ of the water is significantly different. In water bodies, $\mathrm{pH}$ depends on the quality, quantity and types of discharged chemicals and wastes; death and decay of organic matter of plants, animals and their products; flow rate, volume, depth of water; and its interaction with lithosphere and atmosphere. Based on average $\mathrm{pH}(8.38 \pm 0.31)$ value, water is slightly alkaline from S3 to S10 sampling stations due to lots of discharge of untreated wastes from the slum, sewerage and industries.

Levels of dissolved oxygen varies between $(3.12 \pm 0.4 \mathrm{mg} / \mathrm{l})$ and $(5.98 \pm 0.5 \mathrm{mg} / \mathrm{l})$ at sampling station S6 and S1 respectively. The overall average value $(4.03 \pm 0.49 \mathrm{mg} / \mathrm{l})$ of dissolved oxygen is low but the lowest level $(3.12 \pm 0.4 \mathrm{mg} / \mathrm{l})$ of dissolved oxygen is at sampling station S6 (Figure 2). Water flow rate is slow due to even topography of the study area and no turbulence to do aeration. Using ANOVA test, pvalue $(\mathrm{p}=0.001 \leq 0.05)$ of dissolved oxygen in water samples collected from S1-S10 sampling stations is significantly different. Even at 1st sampling station (S1) within the swamp, level of dissolved oxygen is $(5.98 \pm 0.5 \mathrm{mg} / \mathrm{l})$ less than recommended International Standards $[34,35]$. The main reason of low dissolved oxygen is shallow water, slow flow rate, high temperature $\left(25^{\circ} \mathrm{C}\right)$, presence of many micro and macroscopic plants and animal species, contamination of dead organic matter, all types of suspended pollutants, sediments load, and very slow water movement on flat land surface [8]. Rate of metabolic activity, diffusion, atmospheric pressure, temperature, flow rate, and proximity to the atmosphere effects volume of dissolved oxygen in water [28]. Low levels of dissolved oxygen in the water body is due to its low volume, high evapotranspiration, high density of micro and macro-organisms, slow flow rate, low turbulence, low aeration, slow wind velocity, and longer exposure to solar radiation [6].

Electrical conductivity fluctuates between $(839.65 \pm 39.15 \mu / \mathrm{cm})$ and $(381.25 \pm 20.45 \mu / \mathrm{cm})$ but an overall average value of conductivity is $644.42 \pm 28.48 \mu / \mathrm{cm}$ (Table 1 ). ANOVA test shows that $\mathrm{p}$-value is not 
Citation: Manohar S (2018) Physicochemical Parameters and Planktonic Species as Indicators to Assess Water Quality of River Basin and Winam (Nyanza) Gulf of Lake Victoria Catchment, Kisumu County, Kenya (East Africa). J Environ Anal Toxicol 8: 560. doi: $10.4172 / 2161-0525.1000560$

Page 5 of 9

significantly different $(\mathrm{p}=0.327>0.05)$. Conductivity levels in water bodies are influenced by total dissolved chemicals, suspended solids, submerged, attached and floating organisms; growth, density, death and decay of aquatic organisms in water body; sediment load due to run off and soil erosion from the catchment areas and impacts of human activities. Variations in conductivity may be due to duration of standing water, presence of dissolved solids from catchment areas, ion exchange between sediments and water in reservoirs [12] and conductivity also changes due to internal filling of water reservoir [14]. Ecological factors also influence the conductivity of water body due to high rate of evapotranspiration, poor light penetration due to closed cover of free floating, attached and submerged hydrophytes; soil erosion and deposition; depth, flow rate and volume of water; number of inlets and outlets [4]. Conductivity levels are high in most of the sampling stations (S3 to S10) because every day unexpected, untreated large quantities and volumes of industrial effluents, municipal wastes from fish processing, slaughter houses; match box, cotton and food processing; automobile service stations, disposal of Lead batteries; and detergent industries are discharging wastes in or near by these water bodies within study area. In addition to all this, erosion of agrochemicals from farms, washing of many cars, trucks, tankers, buses, containers of chemicals, petroleum, milk, meat, cooking oils and washing soaps are daily routine along the sampling points from S3 to S6. Similar activities are also common along sampling stations S9 and S10 (Figure 2).

Turbidity exhibited wide variations and fluctuates between $(32.37 \pm$ $5.21 \mathrm{NTU})$ and (134.98 $\pm 18.97 \mathrm{NTU})$ at sampling stations S1 and S5 respectively (Table 1$)$ but overall average value of turbidity is $(86.03 \pm$ 15.22 NTU). Sampling station S1 has the lowest turbidity (32.37 \pm 5.21 NTU) that can be attributed to clean water due to filtering efficiency of Nyalenda swamp. Sampling station S5 has highest turbidity (134.98 \pm 18.97 NTU) due to lots of discharge of untreated sewerage; poor sanitation, wastes from industries and Obunga slum around sampling stations S3, S4 and S5 (Figure 2). Based on ANOVA test turbidity shows no significant difference $(\mathrm{p}=0.128>0.05)$ in sampling stations. Turbidity of these water bodies depends on the composition, growth, distribution; stratification of all types of micro and macro aquatic organisms; number of inlets and outlets; sediment load due to soil erosion; impacts of rain intensity, runoff, rate of infiltration, light intensity and wind velocity; re-suspended sediments from the bottom of the water bodies, quantity and quality of discharged wastes, decomposition of organic matter; emergence and submergence of wetland and also on seral stage(s) during aquatic succession from sampling stations S1 to S5 within the river basin, and from sampling stations S6 to S10 within Winam/Nyanza Gulf (Figure 2). Phytoplankton which inhibit the upper eutrophic layer are the main causes of high turbidity if density increases [5]. Turbidity effects on chlorination efficiency and bacterial persistence in water [33].

\section{Chemical parameters}

Mean monthly alkalinity levels fluctuate between $(96.28 \pm 45.24$ $\mathrm{mg} / \mathrm{l})$ and $(199.32 \pm 29.58 \mathrm{mg} / \mathrm{l})$ at sampling stations $\mathrm{S} 1$ and S5 respectively but an average value of alkalinity of all the ten (S1-S10) sampling stations is $(127.46 \pm 31.41)$. ANOVA test revealed that mean $\mathrm{p}$-value of alkalinity is significantly different $(\mathrm{p}=0.001 \leq 0.05)$. Alkalinity levels depend on the concentration of dissolved carbonates, bicarbonates and hydroxyl ions present in water due to death and decay of aquatic flora and fauna; amount of carbon dioxide generated in the water body; types of paternal rocks on the basement and within surroundings; interactions between atmosphere, water body and human activities. Highest alkalinity level is $(199.32 \pm 29.58 \mathrm{mg} / \mathrm{l})$ at sampling station S5 due to slow water flow; continuous discharge of wastes from slum, untreated sewerage from industries and surrounding areas. Alkalinity levels have decreased in sampling stations S8 and S10 (Table 1) within Winam Gulf (Figure 2) which is huge waterbody the source of dilution; absorption of nutrients by floating (Pistia sp., Eichhornia crassipes) and submerged (Ceretophyllum sp.) angiosperms, phytoplanktons, growth of algal species and other micro and macro hydrophytes/organisms within this water body.

Mean monthly minimum and maximum levels of total nitrogen $(388.56 \pm 68.25 \mu \mathrm{g} / \mathrm{l}),(908.88 \pm 363.96 \mu \mathrm{g} / \mathrm{l})$ and phosphorus $(329.21 \pm$ $102.54 \mu \mathrm{g} / 1),(1246.38 \pm 424.28 \mu \mathrm{g} / 1)$ respectively at S1 and S5 sampling stations. Average values of total nitrogen and phosphorus are $(671.11 \pm 176.99 \mu \mathrm{g} / 1)$ and $(796.66 \pm 197.12 \mu \mathrm{g} / 1)$ respectively (Table 1). ANOVA test shows no significant difference between the values of total nitrogen $(\mathrm{p}=0.421>0.05)$ and total phosphorus $(\mathrm{p}=0.419>0.05)$. The high nutrient levels of total nitrogen $(908.88 \pm 363.96 \mu \mathrm{g} / \mathrm{l})$ and phosphorus $(1246.38 \pm 424.28 \mu \mathrm{g} / \mathrm{l})$ are at sampling station S5 due to input of uncontrolled, untreated municipal, industrial waste disposal and accumulation of these nutrients from upstream to down-stream. Mean monthly levels of total nitrogen has decreased to (600.35 \pm $129.14 \mu \mathrm{g} / \mathrm{l})$ at Sampling Station S8 and $(611.38 \pm 130.58 \mu \mathrm{g} / \mathrm{l})$ at sampling S10 due to huge amount of water in Winam Gulf is the source of dilution. Monthly average levels of total phosphorus has also decreased from the maximum level $(1246.38 \mu \mathrm{g} / \mathrm{l})$ at $\mathrm{S} 5$ to approximately half $(641.35 \mu \mathrm{g} / \mathrm{l})$ and $(657.56 \mu \mathrm{g} / \mathrm{l})$ at sampling stations S8 and S10 respectively (Table 1). All organisms require and absorb phosphorus as one of the most essential genetic material as micronutrient from the water body or organic matter or from sediments. High variations in total nitrogen and total phosphorus concentrations are due to the impacts of domestic animals, industrial waste disposal from slaughter houses, detergents, fish processing, sewage disposal; natural death, decay and accumulation of organic matter during succession within wetlands.

Silicate concentration varies between $(3.8 \pm 0.37 \mathrm{mg} / \mathrm{l})$ and $(4.58 \pm$ $1.65 \mathrm{mg} / \mathrm{l})$ within the study area. An overall average value of silicate is $(4.27 \pm 1.05 \mathrm{mg} / \mathrm{l})$. Using ANOVA test, $\mathrm{p}$-value of silicate shows significant difference $(\mathrm{p}=0.004 \leq 0.05)$. The highest silicate level $(4.58 \pm$ $1.65 \mathrm{mg} / \mathrm{l})$ is at sampling station S5 due to lots of anthropogenic activities along the river before it merges with Winam/Nyanza Gulf. The lowest level of silicate $(3.8 \pm 0.37 \mathrm{mg} / \mathrm{l})$ is at sampling station S6 because silica is used by planktons/diatoms, absorbed by attached, submerged and free floating angiosperms, algal species, and also by other aquatic organisms. Silicate level is slightly more $(4.58 \pm 1.65$ $\mathrm{mg} / \mathrm{l}$ ) in the water of river basin at sampling station (S5) in comparison to sampling stations $\mathrm{S} 8$ and $\mathrm{S} 10(4.42 \mathrm{mg} / \mathrm{l}$ and $4.49 \mathrm{mg} / \mathrm{l})$ respectively within Nyanza Gulf (Table 1).

Chlorophyll-a levels fluctuate between $(93.57 \mathrm{mg} / \mathrm{l})$ and $(223.14$ $\mathrm{mg} / \mathrm{l}$ ) within all ten sampling stations. An average value of Chlorophyll-a of all planktonic species collected from ten (S1 to S10) sampling stations is $(147.06 \pm 56.44 \mathrm{mg} / \mathrm{l})$. There is a gradual increase in levels of Chlorophyll-a from (S1 to S6) sampling stations (93.57 \pm $20.26 \mathrm{mg} / \mathrm{l}),(97.82 . \pm 21.15 \mathrm{mg} / \mathrm{l}),(105.86 \pm 24.59 \mathrm{mg} / \mathrm{l}),(153.98 \pm$ $33.46 \mathrm{mg} / \mathrm{l}),(186.88 \pm 35.15 \mathrm{mg} / \mathrm{l})$ and $(213.14 \pm 74.30 \mathrm{mg} / \mathrm{l})$ respectively but levels of Chlorophyll-a decreased from S7 to S10 sampling stations (Table 1). These variations are due to frequency, density and coverage of planktonic species present in river basin and 
Citation: Manohar S (2018) Physicochemical Parameters and Planktonic Species as Indicators to Assess Water Quality of River Basin and Winam (Nyanza) Gulf of Lake Victoria Catchment, Kisumu County, Kenya (East Africa). J Environ Anal Toxicol 8: 560. doi: $10.4172 / 2161-0525.1000560$

Page 6 of 9

within Winam/Nyanza Gulf which is the source of huge water volume being part of Lake Victoria.

The study revealed that $\mathrm{pH}$, dissolved oxygen, alkalinity and silicate show significant difference $(\mathrm{p}=0.001 \leq 0.05)$ in all sampling stations (Table 1) within the study area (Figure 2) along swamp (S1), river basin (S2 to S5) and Winam Gulf (S6 to S10). Levels of conductivity, turbidity, total nitrogen and total phosphorus are very high than permissible levels according to WHO [34], EU [35], KEBS [36] and NEMA [37] standards. Based on these International and Local standards, the water quality of the river basin and Winam /Nyanza Gulf section near Kisumu city is not good for human and animal drinking.

\section{Planktonic species composition}

Out of these total 28 species collected, identi ied and recorded (Table 2), it has been noticed that the number of genera and their species composition are different in all the ten (S1-S10) sampling stations with the presence (+) and or absence (-) of each species based on their own specific adaptations within the levels of physicochemical parameters (Table 1). Sampling station S1 has the presence (+) of 18 species but with absence (-) of 10 species. Sampling station S2 shows the presence $(+)$ of the highest number of 23 species and absence $(-)$ of 5 species which is lowest. Sampling station S3 has the presence (+) of the lowest number of 15 species but absence (-) of 13 species is the highest. Sampling station S4 has the presence (+) of 17 species but 11 species are absent. Sampling station S5 is highly polluted, while S10 is less polluted but both these sampling stations have the presence $(+)$ of 19 species and absence (-) of 9 species with different species composition. Within sampling station S6, there are 18 species present (+) and has the absence (-) of 10 species. Sampling station S7 shows the presence $(+)$ of 16 species and absence (-) of 12 species. Sampling station S8 has the presence $(+)$ of 20 species and shows the absence $(-)$ of 8 species but in sampling station $S 9$, there are 17 species present $(+)$ and 11 species are absent (-).

\begin{tabular}{|c|c|c|c|c|c|c|c|c|c|c|c|c|}
\hline \multirow{2}{*}{ Genera } & \multirow{2}{*}{ Planktonic species } & \multicolumn{10}{|c|}{ Sampling Stations } & \multirow{2}{*}{$\begin{array}{l}\text { Frequency } \\
(\%)\end{array}$} \\
\hline & & s1 & s2 & s3 & S4 & S5 & s6 & s7 & s8 & s9 & S10 & \\
\hline \multirow{2}{*}{ 1. Amphora } & (i) Amphora ovalis & $(-)$ & $(+)$ & $(-)$ & $(+)$ & $(-)$ & $(-)$ & $(+)$ & $(+)$ & $(+)$ & $(-)$ & 50 \\
\hline & (ii) Amphora sp & $(-)$ & $(+)$ & $(-)$ & $(+)$ & $(-)$ & $(+)$ & $(+)$ & $(+)$ & $(+)$ & $(+)$ & 70 \\
\hline \multirow{3}{*}{ 2. Aulacoseira } & (i) Aulacoseira ambigua & $(+)$ & $(+)$ & $(-)$ & $(+)$ & $(+)$ & $(+)$ & $(-)$ & $(+)$ & $(+)$ & $(+)$ & 80 \\
\hline & (ii) Aulacoseira nyassensis & $(+)$ & $(+)$ & $(+)$ & $(-)$ & $(+)$ & $(+)$ & $(-)$ & $(+)$ & $(+)$ & $(+)$ & 80 \\
\hline & (iii) Aulacoseira schroidera & $(-)$ & $(+)$ & $(+)$ & $(-)$ & $(-)$ & $(-)$ & $(-)$ & $(+)$ & $(-)$ & $(-)$ & 30 \\
\hline 3. Closterium & (i). Closterium aciculare & $(+)$ & $(+)$ & $(-)$ & $(-)$ & $(-)$ & $(-)$ & $(-)$ & $(-)$ & $(-)$ & $(-)$ & 20 \\
\hline \multirow{2}{*}{ 4. Cyclotella } & (i) Cyclotella ocellata & $(-)$ & $(-)$ & $(-)$ & $(+)$ & $(-)$ & $(+)$ & $(-)$ & $(-)$ & $(-)$ & $(+)$ & 30 \\
\hline & (ii) Cyclotella kutzinghiana & $(+)$ & $(+)$ & $(+)$ & $(-)$ & $(+)$ & $(+)$ & $(+)$ & $(+)$ & $(+)$ & $(-)$ & 80 \\
\hline \multirow{2}{*}{ 5. Cymbella } & (i) Cymbella cistula & $(+)$ & $(+)$ & $(+)$ & $(+)$ & $(+)$ & $(+)$ & $(+)$ & $(+)$ & $(+)$ & $(+)$ & \\
\hline & (ii) Cymbella sp & $(+)$ & $(+)$ & $(+)$ & $(+)$ & $(+)$ & $(+)$ & $(+)$ & $(+)$ & $(+)$ & $(+)$ & 100 \\
\hline \multirow{3}{*}{ 6. Diatoma } & (i) Diatoma elongatum & $(+)$ & $(+)$ & $(-)$ & $(+)$ & $(-)$ & $(+)$ & $(+)$ & $(+)$ & $(+)$ & $(+)$ & 80 \\
\hline & (ii) Diatoma hiemiale & $(+)$ & $(+)$ & $(+)$ & $(+)$ & $(+)$ & $(+)$ & $(+)$ & $(+)$ & $(+)$ & $(+)$ & 100 \\
\hline & (iii) Diatoma valgare & $(+)$ & $(+)$ & $(-)$ & $(-)$ & $(-)$ & $(-)$ & $(-)$ & $(-)$ & $(-)$ & $(-)$ & 20 \\
\hline \multirow{2}{*}{ 7. Fragilaria } & (i) Fragilaria aethiopica & $(+)$ & $(+)$ & $(-)$ & $(+)$ & $(-)$ & $(+)$ & $(-)$ & $(+)$ & $(-)$ & $(-)$ & 50 \\
\hline & (ii) Fragillaria longissimi & $(-)$ & $(-)$ & $(-)$ & $(-)$ & $(+)$ & $(-)$ & $(-)$ & $(-)$ & $(-)$ & $(-)$ & 10 \\
\hline 8.Gomphocymbella & (i) Gomphocymbella beccari & $(-)$ & $(-)$ & $(-)$ & $(-)$ & $(+)$ & $(-)$ & $(-)$ & $(-)$ & $(-)$ & $(-)$ & 10 \\
\hline \multirow{2}{*}{ 9. Navicula } & (i) Navicula sp & $(-)$ & $(+)$ & $(+)$ & $(+)$ & $(-)$ & $(+)$ & $(+)$ & $(+)$ & $(+)$ & $(+)$ & 80 \\
\hline & (ii) Navicula granatum & $(+)$ & $(+)$ & $(+)$ & $(+)$ & $(+)$ & $(+)$ & $(+)$ & $(+)$ & $(+)$ & $(+)$ & 100 \\
\hline \multirow{4}{*}{ 10. Nitzschia } & (i) Nitzschia dessipata & $(-)$ & $(+)$ & $(+)$ & $(-)$ & $(+)$ & $(+)$ & $(+)$ & $(-)$ & $(-)$ & $(+)$ & 60 \\
\hline & (ii) Nitzschia lucastris & $(+)$ & $(+)$ & $(+)$ & $(+)$ & $(+)$ & $(+)$ & $(+)$ & $(+)$ & $(+)$ & $(+)$ & 100 \\
\hline & (iii) Nitzschia palea & $(+)$ & $(+)$ & $(+)$ & $(+)$ & $(+)$ & $(+)$ & $(+)$ & $(+)$ & $(+)$ & $(+)$ & 100 \\
\hline & (iv) Nitzchia recta & $(+)$ & $(+)$ & $(+)$ & $(+)$ & $(+)$ & $(+)$ & $(+)$ & $(+)$ & $(+)$ & $(+)$ & 100 \\
\hline
\end{tabular}


Citation: Manohar S (2018) Physicochemical Parameters and Planktonic Species as Indicators to Assess Water Quality of River Basin and Winam (Nyanza) Gulf of Lake Victoria Catchment, Kisumu County, Kenya (East Africa). J Environ Anal Toxicol 8: 560. doi: $10.4172 / 2161-0525.1000560$

Page 7 of 9

\begin{tabular}{|c|c|c|c|c|c|c|c|c|c|c|c|c|}
\hline & (v) Nitzschia sub-acicularis & $(+)$ & $(+)$ & $(+)$ & $(+)$ & $(+)$ & $(+)$ & $(+)$ & $(+)$ & $(+)$ & $(+)$ & 100 \\
\hline 11. Pinnularia & (i) Pinnularia viridis & $(-)$ & $(-)$ & $(-)$ & $(+)$ & $(+)$ & $(-)$ & $(-)$ & $(-)$ & $(-)$ & $(-)$ & 20 \\
\hline 12.Stephomodiscus & (i) Stephomodiscus astraca & $(-)$ & $(+)$ & $(+)$ & $(-)$ & $(+)$ & $(-)$ & $(-)$ & $(-)$ & $(+)$ & $(+)$ & 50 \\
\hline 13. Surilella & (i) Surilella ovalis & $(+)$ & $(+)$ & $(+)$ & $(-)$ & $(+)$ & $(+)$ & $(-)$ & $(+)$ & $(+)$ & $(+)$ & 80 \\
\hline \multirow{2}{*}{ 14. Synedra } & (i) Synedra cunningtonii & $(+)$ & $(-)$ & $(-)$ & $(+)$ & $(+)$ & $(-)$ & $(+)$ & $(+)$ & $(-)$ & $(+)$ & 60 \\
\hline & (ii) Synedra ulna & $(+)$ & $(+)$ & $(-)$ & $(-)$ & $(+)$ & $(-)$ & $(+)$ & $(+)$ & $(-)$ & $(+)$ & 60 \\
\hline \multicolumn{2}{|c|}{ Number of species present $(+)$} & 18 & 23 & 15 & 17 & 19 & 18 & 16 & 20 & 17 & 19 & \\
\hline \multicolumn{2}{|c|}{ Number of species absent (-) } & 10 & 5 & 13 & 11 & 9 & 10 & 12 & 8 & 11 & 9 & \\
\hline
\end{tabular}

Table 2: Planktonic genera, their species composition and distribution with presence (+) or absence (-) within ten (S1-S10) sampling stations along wetlands of Nyalenda swamp (S1), River Kisat (S2-S5) and Winam Gulf (S6-S10) part of Lake Victoria Basin, Kisumu County, Kenya (February to July 2017).

Species with $100 \%$ frequency belong to four genera composed of eight species: Cymbella cistula, Cymbella sp, Diatoma hiemiale, Navicula granatum, Nitzschia lucastris, $N$. palea, N. recta and N. subacicularis which are present (+) in all the ten (S1 to S10) sampling stations (Table 2) with high tolerance range of mean monthly levels of $\mathrm{pH}$ (6.96 to 9.98), dissolved oxygen (3.12 $\mathrm{mg} / \mathrm{l}$ to $5.98 \mathrm{mg} / \mathrm{l})$; conductivity ( $381.25 \mu \mathrm{S} / \mathrm{cm}$ to $839.65 \mu \mathrm{S} / \mathrm{cm}$ ); turbidity (32.37 NTU to $134.98 \mathrm{NTU})$; alkalinity $(96.28 \mathrm{mg} / \mathrm{l}$ to $199.32 \mathrm{mg} / \mathrm{l})$; total nitrogen (388.56 $\mu \mathrm{g} / 1$ to $908.88 \mu \mathrm{g} / 1)$; total phosphorus $(329.21 \mu \mathrm{g} / 1$ to 1246.38 $\mu \mathrm{g} / 1)$ and silicate $(3.8 \mathrm{mg} / \mathrm{l}$ to $4.58 \mathrm{mg} / 1)$.

Only six planktonic species are with $80 \%$ frequency and belong to ive genera: Aulacoseira ambigua; Aulacoseira nyassensis; Cyclotella kutzinghiana; Diatoma elongatum; Navicula sp; and Surilella ovalis. Out of these Navicula sp. is absent in sampling station (S1) due to low turbidity (32.37 NTU) and in S5 due to high total phosphorus (1246.38 $\mu \mathrm{g} / 1)$ and Diatoma elongatum is absent in sampling station S3 and S5 due to very high levels of conductivity $(839.65 \mu \mathrm{S} / \mathrm{cm})$ and high total phosphorus $(1246.38 \mu \mathrm{g} / 1)$ respectively. Aulacoseira ambigua is absent in S3 and S7 due to the sewerage from the slum and other sources. Both species Aulacoseira nyassensis, and Surilella ovalis are absent in S4 and S7; Cyclotella kutzinghiana, is absent in S4 and S10 sampling stations due to daily discharge of all types of untreated wastes from Obunga slum and also from Kisumu sewerage treatment plant directly in this river basin (Figure 2, Table 2).

Only one Amphora sp. appeared with $70 \%$ frequency out of the total 28 planktonic species (Table 2). It is absent in S1, S3 and S5 sampling stations due to low turbidity ( $32.37 \mathrm{NTU}$ ) in S1; very high levels of conductivity $(839.65 \mu \mathrm{S} / \mathrm{cm})$, total phosphorus $(1246.38 \mu \mathrm{g} / 1)$ in $\mathrm{S} 5$ (Table 1).

There are three planktonic species with $60 \%$ frequency (Table 2). All these three species Nitzschia dessipata, Synedra cunningtonii and Synedra ulna are present in sampling stations S5, S7 and S10 but in addition, Nitzschia dessipata is also present in S2, S3, and S6 because it is not adapted in low levels of turbidity (32.17 NTU) and total phosphorus $(329.21 \mu \mathrm{g} / \mathrm{l})$; Synedra cunningtonii is present in S1, S4 and S8 but Synedra ulna is present in S1, S2 and S8. These three species are well adapted in wide range of physicochemical levels of $\mathrm{pH}$ (6.96 to 9.98), conductivity ( 381.25 to $839.65 \mu \mathrm{S} / \mathrm{cm})$, total nitrogen $(388.56$ $\mu \mathrm{g} / \mathrm{l}$ to $908.88 \mu \mathrm{g} / \mathrm{l})$ and all the three species are absent in S9 sampling station (Table 2).
Three species with 50\% frequency are: Amphora ovalis; Fragilaria aethiopica and Stephomodiscus astraca and all the three species are present $(+)$ in sampling station S2. In addition, Amphora ovalis with Fragilaria aethiopica is present in S4 and S8; Amphora ovalis and Stephomodiscus astraca are present in sampling station S9. As an individual species, Amphora ovalis is present in sampling station S7; Fragilaria aethiopica is present in S1 and S6 and Stephomodiscus astraca is present in S3 and S5, and S10 (Table 2) with their own suitable range of physicochemical levels (Table 1).

Species with $30 \%$ frequency are only two: Aulacoseira schroidera and Cyclotella ocellata (Table 2). Aulacoseira schroidera is present in sampling stations S2, S3 and S8 (Table 2) due to its wide range of adaptation of $\mathrm{pH}(7.24$ to 8.21$)$, conductivity $(390.75 \mu \mathrm{S} / \mathrm{cm}$ to 802.64 $\mu \mathrm{S} / \mathrm{cm})$, total nitrogen $(400.77 \mu \mathrm{g} / 1$ to $629.71 \mu \mathrm{g} / 1)$ and total phosphorus $(342.17 \mu \mathrm{g} / 1$ to $776.14 \mu \mathrm{g} / 1)$ but Cyclotella ocellata is present in (S4, S6, and S10) sampling stations (Table 2) and well adopted within levels of dissolved oxygen $(3.32 \mathrm{mg} / \mathrm{l}$ to $4.23 \mathrm{mg} / \mathrm{l})$, high conductivity $(657.31 \mu \mathrm{S} / \mathrm{cm}$ to $799.43 \mu \mathrm{S} / \mathrm{cm})$, alkalinity $(104.45$ $\mathrm{mg} / \mathrm{l}$ to $171.16 \mathrm{mg} / \mathrm{l})$, total nitrogen $(611.38 \mu \mathrm{g} / 1$ to $877.14 \mu \mathrm{g} / 1)$, total phosphorus $(657.56 \mu \mathrm{g} / 1$ to $1164.24 \mu \mathrm{g} / 1)$ and silicate $(3.8 \mathrm{mg} / \mathrm{l}$ to 4.49 $\mathrm{mg} / \mathrm{l})$, (Table 1).

Species with 20\% frequency are: Closterium aciculare, Diatoma valgare and Pinnularia viridis (Table 2). Out of these three species, two species namely $C$. aciculare, and $D$. valgare are present in S1 and S2 sampling stations and well adapted within low levels of $\mathrm{pH}$ (6.96 to $7.24)$, dissolved oxygen $(5.32 \mathrm{mg} / \mathrm{l}$ to $5.98 \mathrm{mg} / \mathrm{l})$, conductivity $(381.25$ $\mu \mathrm{S} / \mathrm{cm}$ to $390.75 \mu \mathrm{S} / \mathrm{cm}$ ), low turbidity (32.37 NTU to $62.35 \mathrm{NTU}$ ), low alkalinity $(96.28 \mathrm{mg} / \mathrm{l}$ to $98.58 \mathrm{mg} / \mathrm{l})$, total nitrogen $(388.56 \mu \mathrm{g} / 1$ to $400.77 \mu \mathrm{g} / 1)$ and total phosphorus $(329.21 \mu \mathrm{g} / 1$ to $342.17 \mu \mathrm{g} / 1)$; but Pinnularia viridis is present in different sampling stations S4 and S5 (Tables 1 and 2) within low levels of dissolved oxygen (3.19 to 3.32 $\mathrm{mg} / \mathrm{l})$, high conductivity $(796.45$ to $839.65 \mu \mathrm{S} / \mathrm{cm})$, high alkalinity $(164.51 \mathrm{mg} / \mathrm{l}$ to $199.32 \mathrm{mg} / \mathrm{l})$, total nitrogen $(720.87 \mu \mathrm{g} / 1$ to 908.88 $\mu \mathrm{g} / 1)$ and high total phosphorus $(1028.77 \mu \mathrm{g} / 1$ to $1246.38 \mu \mathrm{g} / 1)$.

Species with $10 \%$ frequency are: Fragillaria longissimi and Gomphocymbella beccari which are present only in sampling station S5 (Table 2) within specific range of physicochemical levels (Table 1). These both planktonic species Fragillaria longissimi and Gomphocymbella beccari are the indicators of low dissolved oxygen (3.19 mg/l), high $\mathrm{pH}$ (9.98), high conductivity $(839.65 \mu \mathrm{S} / \mathrm{cm})$, high 
Citation: Manohar S (2018) Physicochemical Parameters and Planktonic Species as Indicators to Assess Water Quality of River Basin and Winam (Nyanza) Gulf of Lake Victoria Catchment, Kisumu County, Kenya (East Africa). J Environ Anal Toxicol 8: 560. doi: $10.4172 / 2161-0525.1000560$

Page 8 of 9

turbidity (134.98 NTU), high alkalinity (199.32 mg/l) and very high levels of total nitrogen $(908.88 \mu \mathrm{g} / \mathrm{l})$ and phosphorus $(1246.38 \mu \mathrm{g} / \mathrm{l})$.

Each planktonic species is an indicator species of its own habitats and shows its presence in low or high levels of physicochemical parameters, but some species are well adopted within wide range of physicochemical levels. Therefore, planktonic species and physicochemical parameters, both are good indicators depending upon their levels of presence to take the correct judgement about good or poor water quality of any wetland. The average values of $\mathrm{pH}(8.38)$; dissolved oxygen $(4.03 \mathrm{mg} / \mathrm{l})$; conductivity $(644.42 \mu \mathrm{S} / \mathrm{cm})$, turbidity $(86.03 \mathrm{NTU})$, alkalinity $(127.46 \mathrm{mg} / \mathrm{l})$, total nitrogen $(671.11 \mu \mathrm{g} / \mathrm{cm})$ and phosphorus $(796.66 \mu \mathrm{g} / \mathrm{l})$ are the indicators of poor water quality within the study area (Table 1). Therefore, the presence of planktonic species in such waterbodies with poor water quality is the direct approach and practical evidence that species are also equally good indicators as the physicochemical parameters are to assess the water quality of any wetland.

\section{Conclusion}

Based on these results of our study, it is concluded that there is close relationship and interaction between planktonic species and physicochemical parameters. Therefore, composition, distribution or frequency of the species should be considered and used as good indicator(s) or bio-indicator(s) in the field for quick assessment of water quality of any natural or man-made wetlands/aquatic ecosystems for the present and future predictions about their performance(s) and function(s). The presence of high diversity and frequency of planktonic species; and or high levels of chemical contaminations within water bodies of any area of any country is the direct signal of mismanagement of their water resources and with time that polluted water body will not support healthy life. Therefore, public awareness should be created and strong enforcement of environmental laws must be practiced to protect these waterbodies and to maintain healthy aquatic ecosystem(s) for healthy environment.

\section{References}

1. Ndeda LA, Manohar S (2014) Bio Concentration Factor and Translocation Ability of Heavy Metals Within Different Habitats of Hydrophytes in Nairobi Dam, Kenya. J Environ Sci Toxicol Food Technol 8: 42-45.

2. Gilcreas FW (1966) Standard methods for the examination of water and waste water. American Journal of Public Health and the Nations Health 56: 387-388.

3. Taylor JC, de La Rey PA, van Rensburg L (2005) Recommendations for the collection, preparation and enumeration of diatoms from riverine habitats for water quality monitoring in South Africa. African Journal of Aquatic Science 30: 65-75.

4. Manohar S, Kitur EL, Kibet FC (2016) Water Quality and Plant Species Composition of Chemususu Dam, Baringo County, Kenya. J Environmental \& Analytical Toxicology 6: 390

5. Madsen JD, Wersal RM (2012) A Review of Aquatic Plant Monitoring and Assessment Methods. Aquatic Ecosystem Restoration Foundation, Marietta, Atlanta.

6. Manohar S, Mangoka JM, Ndunda E, Gathuru G (2017) Assessment of Yatta Canal Water Quality for Irrigation, Machokos County, Kenya. J Environmental \& Analytical Toxicology 7: 423.

7. Wetzel RG (2001) Limnology: Lake and River Ecosystems. 3rd edn. Academic Press, San Diego, USA, p: 1006.

8. Manohar S, Otieno AA, Kitur EL (2017) Planktonic Diatoms Species Composition and Water Characteristics Along Selected Sites of River
Kisat, Kisumu County, Kenya. J Environmental \& Analytical Toxicology 7: 475 .

9. Khan FA, Ansari AA (2005) Eutrophication: An Ecological Vision. Bot Rev 71: 449-482.

10. Smol JP (2008) Pollution of Lakes and Rivers: A Paleoenvironmental Perspective. 2nd edn. John Wiley \& Sons, USA.

11. Grabowska M (2012) The Role of a Eutrophic Lowland Reservoir in Shaping the Composition of River Phytoplankton. Ecohydrology and Hydrobiology 12: 231-242.

12. Kitur EL (2009) Comparative Study on the Influence of Variations in Environmental Factors on the Phytoplankton Properties of Selected Reservoirs in Central Kenya. Unpublished $\mathrm{PhD}$ Thesis, Kenyatta University, Nairobi, Kenya.

13. Ayeni AO, Balogun II, Soneye AS (2011) Seasonal assessment of physicochemical concentration of polluted Urban river: A case of Ala river in Southwestern-Nigeria. Research Journal of Environmental Sciences 5: 22.

14. Lee N, Yee TL, Grinang J (2012) Physico-chemical Characteristics in the Filling Phase of Bakun Hydroelectric Reservoir, Sarawak, Malaysia. International Journal of Applied Science and Technology 2: 92-101.

15. Sunkad B (2013) Water quality of Malaprabha River with Reference to Physicochemical Factors near Khanapur town of Belgaum District, India. International Journal of Innovative research in Science, Engineering and Technology 2: 930-936.

16. Deshmukh CK, Urkude RN (2014) Physico-chemical and microbial status of Malkhed lake at Chandur Railay, District: Amaravati. Journal of Life Sciences 9: 667-682.

17. Qureshimatva UM, Maurya RR, Gamit SB, Patel RD, Solanki HA (2015) Determination of Physico- Chemical Parameters and Water Quality Index (wqi) of Chandlodia Lake, Ahmedabad, Gujarat, India. J Environmental \& Analytical Toxicology 5: 288.

18. Blinn DW, Herbst DB (2003) Use of diatoms and soft algae as indicators of environmental determinants in the Lahontan Basin, USA. Annual Report of Water Resources Board, California State.

19. Walsh G, Wepener V (2009) The influence of land use on water quality and diatom community structures in urban and agriculturally stressed rivers. Water SA 35: 579-594.

20. Masese FO, Muchiri M, Raburu PO (2009) Macroinvertebrate assemblages as biological indicators of water quality in the Moiben River, Kenya. African Journal of Aquatic Science 34: 15-26.

21. Torrisi M, Scuri S, Dell'Uomo A, Cocchioni M (2010) Comparative monitoring by means of diatoms, macroinvertebrates and chemical parameters of an Apennine watercourse of central Italy: The river Tenna. Ecological Indicators 10: 910-913.

22. Lange-Bertalot H (2001) Diatoms of the European Inland Waters and Comparable Habitats. Diatoms of Europe 2: 526.

23. Hill B (2003) Assessment of streams of the eastern United States using a periphyton index of biotic integrity. Ecological Indicators 2: 325-338.

24. Ndeda LA, Manohar S (2014) Determination of heavy metals in Nairobi dam water, (Kenya). IOSR Journal of Environmental Science, Toxicology and Food Technology 8: 68-73.

25. Archibald CG, Taylor JC (2007) The assessment of diffuse pollution from acid-mine drainage using an updated and revised diatom assessment procedure as an added-value bio-monitoring tool. Water Science and Technology 55: 151-60.

26. Duong TT, Morin S, Coste M, Herlory O, Feurtet-Mazel A, et al. (2010). Experimental toxicity and bioaccumulation of cadmium in freshwater periphytic diatoms in relation with biofilm maturity. Science of the Total Environment 408: 552-562.

27. Lung'Ayia HB, M'harzi A, Tackx M, Gichuki J, Symoens JJ (2000) Phytoplankton community structure and environment in the Kenyan waters of Lake Victoria. Freshwater Biology 43: 529-543.

28. Dodds WK (2002) Freshwater Ecology: Concepts and Environmental Applications. Academic Press, California, p: 569. 
Citation: Manohar S (2018) Physicochemical Parameters and Planktonic Species as Indicators to Assess Water Quality of River Basin and Winam (Nyanza) Gulf of Lake Victoria Catchment, Kisumu County, Kenya (East Africa). J Environ Anal Toxicol 8: 560. doi: $10.4172 / 2161-0525.1000560$

Page 9 of 9

29. Otieno AA (2016) Assessment of Water Quality Using Planktonic Diatoms of River Kisat, Lake Victoria Catchment, Kisumu County. Unpublished MSc Thesis, Kenyatta University, Nairobi, Kenya.

30. Aitkenhead-Peterson JA, Nahar N, Harclerode CL, Stanley NC (2011) Effect of urbanization on surface water chemistry in south-central Texas. Urban Ecosystems 14: 195-210.

31. Gulec AK, Yildirim NC, Danabas D, Yildirim N (2011) Some haematological and biochemical parameters in common carp (Cyprinus carpio L., 1758) in Munzur River, Tunceli, Turkey. Asian Journal of Chemistry 23: 910.

32. Fallu MA, Allaire N, Pienitz R (2000) Freshwater Diatoms from Northern Que'bec and Labrador, Canada. Species-Environment Relationships in Lakes of Boreal Forest, Forest Tundra and Tundra Regions. Bibliotheca Diatomologica 45: 200.
33. Levhevallier MW, Evans TM, Seidler RJ (2014) Effect of Turbidity on Chlorination Efficiency and Bacterial Persistence in Drinking Water. Applied and Environmental Microbiology 42: 159-167.

34. WHO (2011) Guideline for drinking water quality. 4th edn. World Health Organization, Geneva, Switzerland 38: 104-108.

35. EU (1998) Council Directive 1998/83/EC on the Quality of Water Intended for Human Consumption. Official Journal of the European Communities, 330/32,11.

36. KEBS (2007) Drinking Water-Specification. Part 1: The Requirements for Drinking Water. 3rd edn. Nairobi: KEBS (KS 459-1: 2007).

37. NEMA (2006) Water Quality Regulations. National Environmental Management Authority, Government Printer, Nairobi, Kenya.

38. Needham J, Needham P (1972) A Freshwater guide to the study of Freshwater Biology. 5th edn. Holden-Day, London. 